\title{
Limnological and ecological methods: approaches, and sampling strategies for middle Xingu River in the area of influence of future Belo Monte Power Plant
}

\author{
Tundisi, JG. ${ }^{a, b *}$, Matsumura-Tundisi, T. ${ }^{a}$, Tundisi, JEM. ${ }^{a}$, Faria, CRL. ${ }^{a}$, Abe, D.S. ${ }^{a}$, \\ Blanco, F. ${ }^{a}$, Rodrigues Filho, J. ${ }^{a}$, Campanelli, L. ${ }^{a}$, Sidagis Galli, C. ${ }^{a}$, Teixeira-Silva, V. \\ Degani, R. ${ }^{a}$, Soares, FS. ${ }^{a}$, Gatti Junior, P. $^{a}$ \\ anstituto Internacional de Ecologia e Gerenciamento Ambiental - IIEGA, \\ Rua Bento Carlos, 750, Centro, CEP 13560-660, São Carlos, SP, Brazil \\ bUniversidade Feevale, Rod. RS 239, 2755, Vila Nova, CEP 93525-075, Novo Hamburgo, RS, Brazil \\ *e-mail: tundisi@iie.com.br
}

Received: July 20, 2015 - Accepted: July 21, 2015 - Distribuited: August 31, 2015

(With 7 figures)

\begin{abstract}
In this paper the authors describe the limnological approaches, the sampling methodology, and strategy adopted in the study of the Xingu River in the area of influence of future Belo Monte Power Plant. The river ecosystems are characterized by unidirectional current, highly variable in time depending on the climatic situation the drainage pattern an hydrological cycle. Continuous vertical mixing with currents and turbulence, are characteristic of these ecosystems. All these basic mechanisms were taken into consideration in the sampling strategy and field work carried out in the Xingu River Basin, upstream and downstream the future Belo Monte Power Plant Units.
\end{abstract}

Keywords: limnology, sampling strategies, Xingu River, ecosystem, rivers, Belo Monte Power Plant.

\section{Estudo limnológico e da biota aquática no Rio Xingu na área de influência de UHE Belo Monte: metodologia e abordagens}

\section{Resumo}

Neste trabalho os autores descrevem as abordagens limnológicas e a metodologia e estratégia de amostragem adotadas no estudo do Rio Xingu, na área de influência da futura Usina da Belo Monte (UHE Belo Monte). O ecossistema de rios é caracterizado por velocidade unidirecional de correntes, muitas flutuações de fluxos dependendo do clima do padrão de drenagem e do ciclo hidrológico. Mistura vertical permanente e turbulências ocorrem constantemente devido a correntes predominantes. Todos estes mecanismos gerais e específicos característicos do Rio Xingu, foram levados em consideração no plano de estudos limnológicos e amostragens desenvolvidas na área de influência de UHE Belo Monte a montante e a jusante do futuro empreendimento.

Palavras-chave: limnologia, estratégias de amostragem, Rio Xingu, ecossistemas, rios, UHE Belo Monte.

\section{Introduction}

The operations involved in limnological studies and water quality assessments, are several and complex. They have a series of links and the failure in any one of these can weaken the whole assessment and produce wrong information. Limnology of rivers are fundamental as a information system in order to evaluate the state of a water body (Tundisi and Matsumura-Tundisi, 2008, 2012).

Furthermore limnological studies and water quality assessments are essential in the design of strategies for future management and follow up of reservoir construction (Tundisi and Straskraba, 1999).

In order to produce comprehensive limnological studies and water quality assessments that are useful to decision makers, the design of the sampling strategies must take into account the precise objectives of the project, its impacts and future developments (Chapman, 1992).

Limnology of rivers and water quality assessments, must therefore be considered as an information system, of present and future status of freshwater ecosystems subjected to impacts such as reservoir construction (Straskraba and Tundisi, 2000). The use of the monitoring has evolved, from mere diagnosis to determine and advance trends in the quality of freshwater ecosystems, and how they are affected by the anthropogenic activities.

In the Amazon Watershed,intensive limnological and water quality studies are even more important due to its 
complexity of the ecological dynamics (Barrow, 1983; Tundisi and Straskraba, 1999; Tundisi and Matsumura-Tundisi, 2013a). The construction and operation of reservoirs in this region depends upon the monitoring and impact assessment before, during construction, and after the reservoir is completed.

\section{Rivers as Ecosystems}

A river differs from other freshwater ecosystems, in two fundamental ways: first the permanent horizontal movement of a river current - unidirectional - and the second is the interaction with its drainage basin, from which a permanent contribution of allocthonous material arises - mainly components of vegetation remains such as leaves, fruits, roots, and erosive materials from the soils. The water motion in the river controls the structure of the bottom and the materials found in the sediment. Fluvial geomorphology determines, the main characteristics of the tributaries. Physical factors, affecting the transport of matter and load include: width, depth of the river channel, the velocity of the flow, the degree of roughness of the sediment, the degree of sinuosity of the river and its major tributaries (Allan, 1995). Rivers are transport systems for particulate and dissolved organic and inorganic matter, for insect larvae, remains of organisms, fish eggs, aquatic plants (Whiton, 1975; Tundisi and Matsumura-Tundisi, 2008, 2013a). The dominant invertebrates in the river are benthic, the dominant vertebrates are fish (Margalef, 1993).

River hydraulics influences the distribution of sediments in the bottom and of the benthic macroinvertebrates (Bettler et al., 2014; Amsler et al., 2009). Large rivers of the Amazon Basin have special features as regards morphometry, volume, seasonal changes in discharge and chemical composition of the water. (Sioli, 1984).

Therefore sampling strategies and environmental impact assessment of this freshwater ecosystem have to take into account these special features.

\section{The Xingu River Watershed}

The Xingu River watershed is located on the right margin of the Amazon River and occupies an area of $520.292 \mathrm{~km}^{2}$ (Figure 1). The Xingu River has its headwaters in the region of the brazilian shield and flows north to discharge in the Amazon River. As classified by Sioli (1975) the Xingu River is a clear water river, with transparency higher than the white water rivers, $\mathrm{pH}$ between 6.0-7.0, well oxygenate waters and low ionic concentration.

The river has a complex morphometry specially near the Amazon River and in the site where it is located the future Belo Monte Power Plant (Figure 2).

One of the main characteristics of this river, is that it has innumerous tributaries. The connection of these tributaries with the main river is a fundamental ecological process that maintain the flux of organic matter to the Xingu River and acts as the marginal lakes as a capacitor of biomass to the main river. The basin is occupied with $25 \%$ of cropland, and has a forest cover of $70 \%$ (Revenga et al., 1998)

\section{Methodological Approaches and Strategies}

Since the determination of limnological variables and water quality assessments are fundamental to analyze present and future impacts and trends the following strategies were part of the design for the spatial and temporal sampling:

- To analyze the adequacy of the water quality to the proposed future multiple uses in the area of influence of the Power Plant, during the construction, filling and operation phase, of the reservoirs.

- To provide precise information to support management of the watershed and water bodies (river, tributaries, reservoirs).

- To provide information on the impact of the construction of Belo Monte Power Plant on the water quality and aquatic biota during the various stages of the construction, filling and operation.

- To provide limnological information to support the mathematical modeling project of the water quality prognosis of the Xingu reservoir, middle reservoir and downstream the Power Plant.

- To promote an interface with the Environmental Plan of Construction; the program of the monitoring of the aquatic Macrophytes; the conservation of fishes species; the Public Health program; the Social Communication plan and the Environmental Education, projects.

- Classification of waters for water uses, followed CONAMA 357/2005 (Brasil, 2005); and CONAMA 454/2012 (Brasil, 2012) for sediment classification was followed.

\subsection{Selection of sampling sites}

The selection of the monitoring stations for assessment of water quality and limnological studies, sediment composition and aquatic biota was based on the results of the Environmental Impact Assessment of 2007, field surveillance, in accordance with IBAMA (2013) and North Energy technical regulations. CONAMA 357 environmental regulation for water quality was followed during all stages of the sampling, field and laboratory work.

Criteria adopted for the selection of sampling sites and sampling stations were based on the impact of the construction work: urban areas, suppression of vegetation, villages, access roads, construction support areas, transmission lines.

\subsection{Temporal strategy of sampling}

Due to the dynamics of the river ecosystem and its response to the interactions climate/hydrology, sampling strategies have to consider the temporal dynamics of the system (represented mainly by the fluvial dynamics) during periods of high water and low water (Tundisi et al., 2008; Martinelli et al., 2012; Agostinho et al., 2009) (Figure 3).

Sampling strategies involved three periods depending on the intensity of the construction work and the need to 


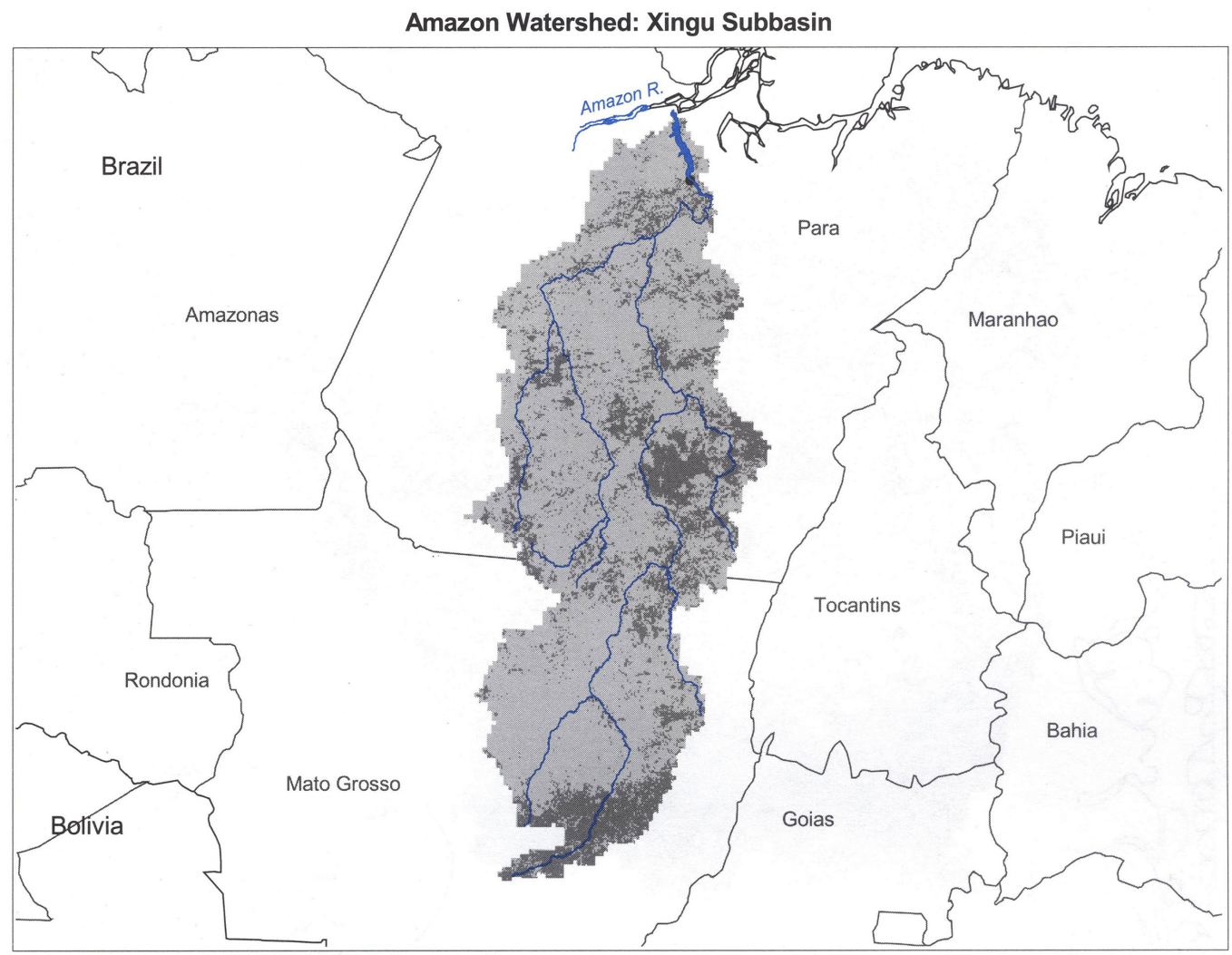

Watershed

- Cities (population > 100,000)

$\triangle$ Ramsar Sites

(Political Boundaries (Intl.)

Political Boundaries (Natl.)

Rivers

Modified Landscape

Figure 1. The Xingu River Basin (Revenga et al. 1998).

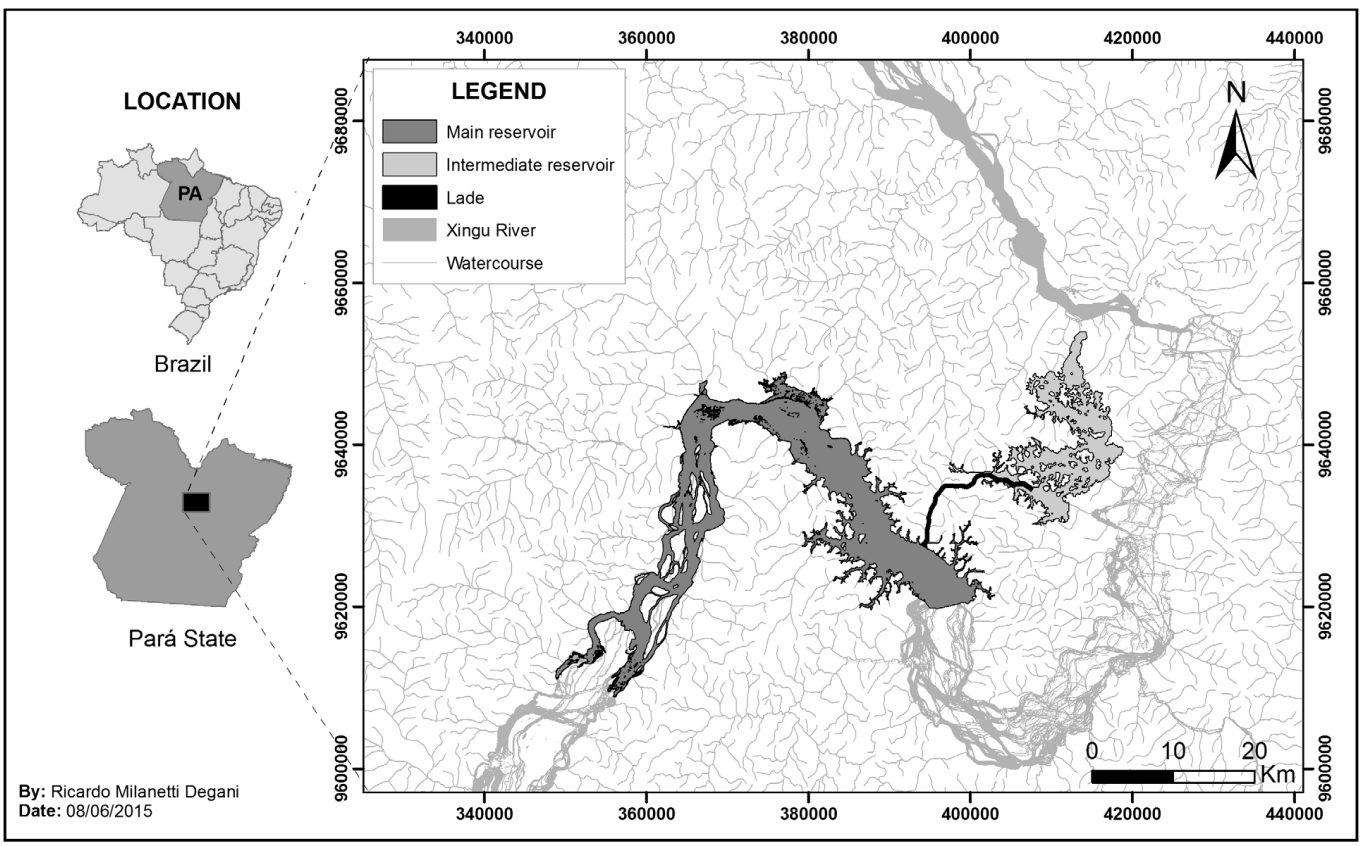

Figure 2. The complex morfometry of Xingu River and its tributaries. 


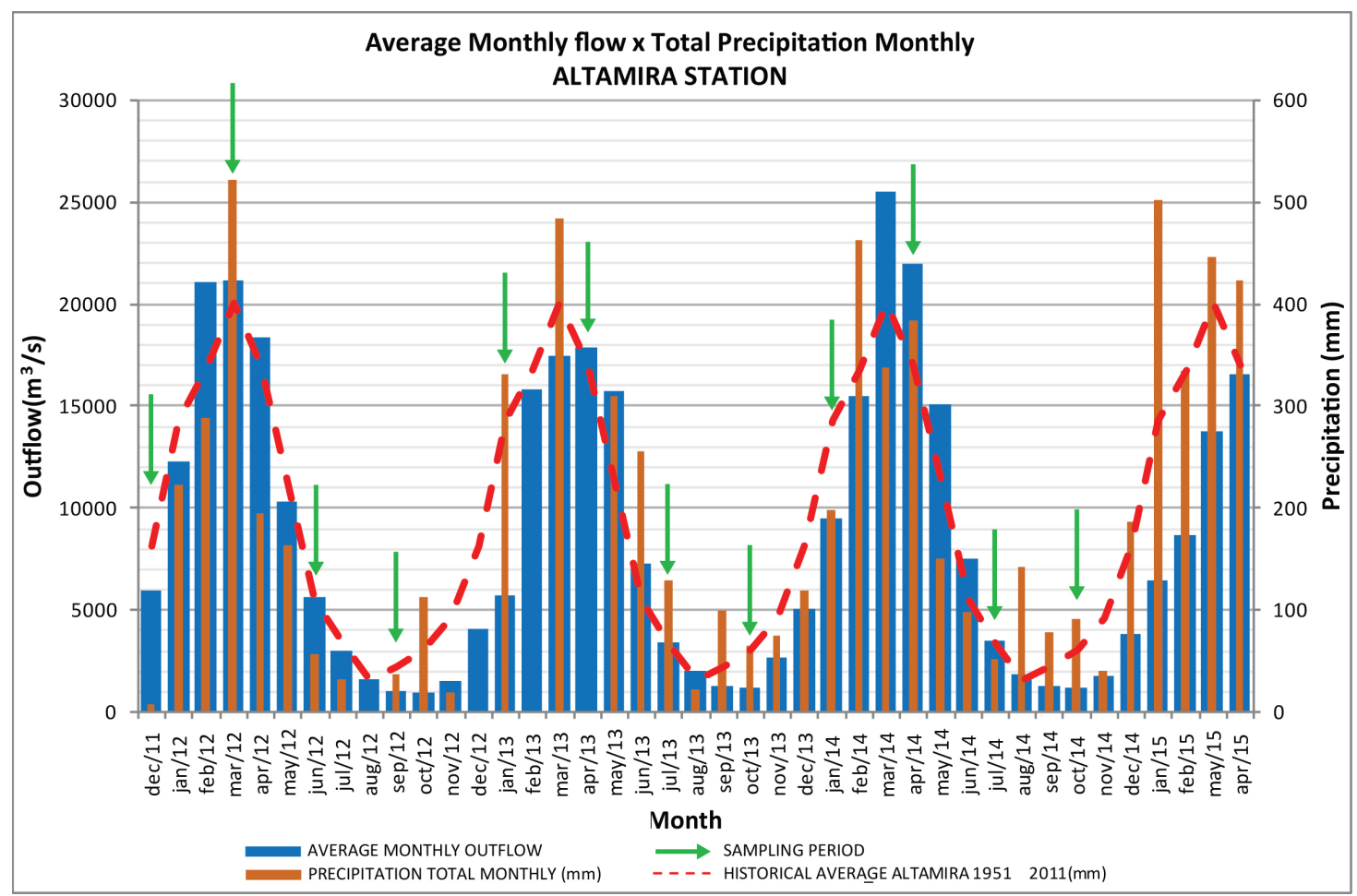

Figure 3. Temporal dynamiscs of the hydrological cycle and the sampling periods.

detect changes in water quality: monthly sampling near the construction site and the transmission lines; weekly sampling upstream and downstream the main reservoir in the Xingu River; general sampling every three months; this was distributed along the Xingu River and tributaries, upstream the main reservoir in the Xingu River, region of reduced flux and downstream the Power Plant. Number of stations: monthly sampling 32 stations; weekly sampling 7 stations; sampling every three months: 35 stations. Figures 4, 5, 6 and 7, shows the sampling stations and their distribution in the river, tributaries and construction sites. Table 1 shows the details of the methods used with references and a brief description of methodology.

Tables 1A, 2A, 3A and 4A (see Annex A) describe the location of the sampling sites with the geographic coordinates.

\section{Limnological Surveys and Water Quality Assessments}

\subsection{General approach}

Any information system based on limnological surveys and water quality must take into account all the physical, chemical and biological components of the river ecosystem. Since rivers are dynamic systems that respond to the physical characteristics of the watershed and are controlled by local and regional geological and climatic conditions, it is necessary to include all the components of the ecosystem in order to understand seasonal variation and all man, induced changes in the aquatic biota that once identified can be used to follow and monitor charges in the river environment. The complexity and components of the assessment programs are defined by the future water uses, the water quality requirements and the determination of the impacts produced by the Power Plant construction (Chapman, 1992; Tundisi and Straskraba, 1999).

\subsection{Multipurpose river quality monitoring programme}

\subsubsection{Sampling methods abiotic parameters}

Sampling of the physical and some chemical parameters was carried out with submersible probes with multiparametric sensors. In situ sampling of water temperature $\left({ }^{\circ} \mathrm{C}\right) ; \mathrm{pH}$; dissolved oxygen $\left(\mathrm{mgxl}^{-1}\right)$, conductivity $\left(\mu \mathrm{S} \mathrm{x} \mathrm{cm}{ }^{-1}\right)$; turbidity (NT units); redox potential and total dissolved solids was carried out routinely in weekly, monthly or every three months periods. Sampling for other chemical variables such as total phosphorus, inorganic phosphate, nitrite, ammonium, nitrate were collected at surface with plastic non toxic bottles, frozen, and analyzed by spectrophotometric or liquid chromatography. Metals were analyzed by atomic absorption spectrophotometry. They were: Aluminum, Copper, Cadmium; Chromium; Lead; total Iron; dissolved Iron; Zinc; Manganese, Magnesium; Arsenium; Mercury and Selenium. Ionic composition of water: Potassium; Sodium; Magnesium; Chloride; Sulphate, Bromium, Fluoride.

Biochemical oxygen demand (DBO 5 20), total suspended material (organic and inorganic) pesticides and herbicides completed the analysis of the abiotic factors. 


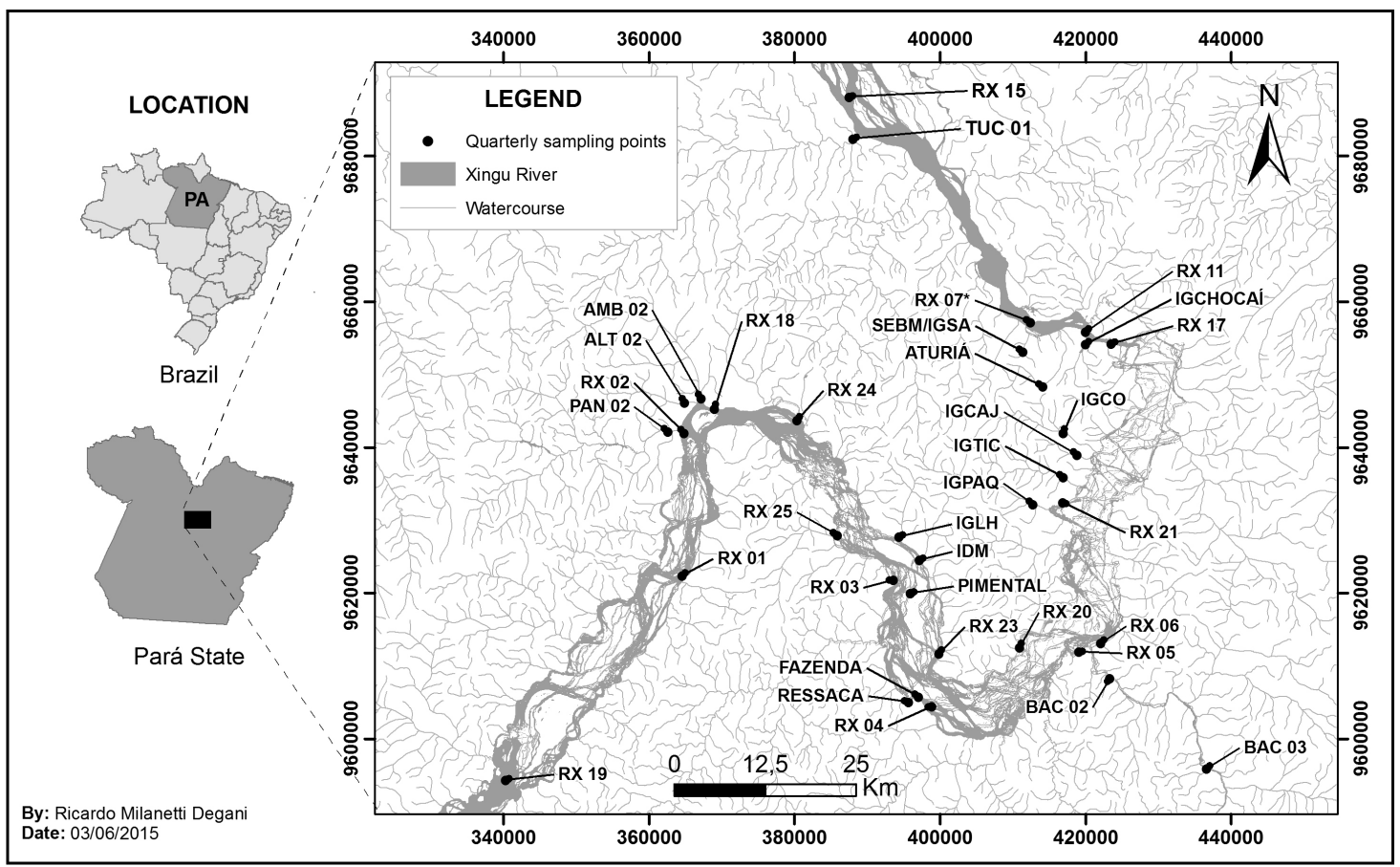

Figure 4. The geographical distribution of the quarterly sampling points.

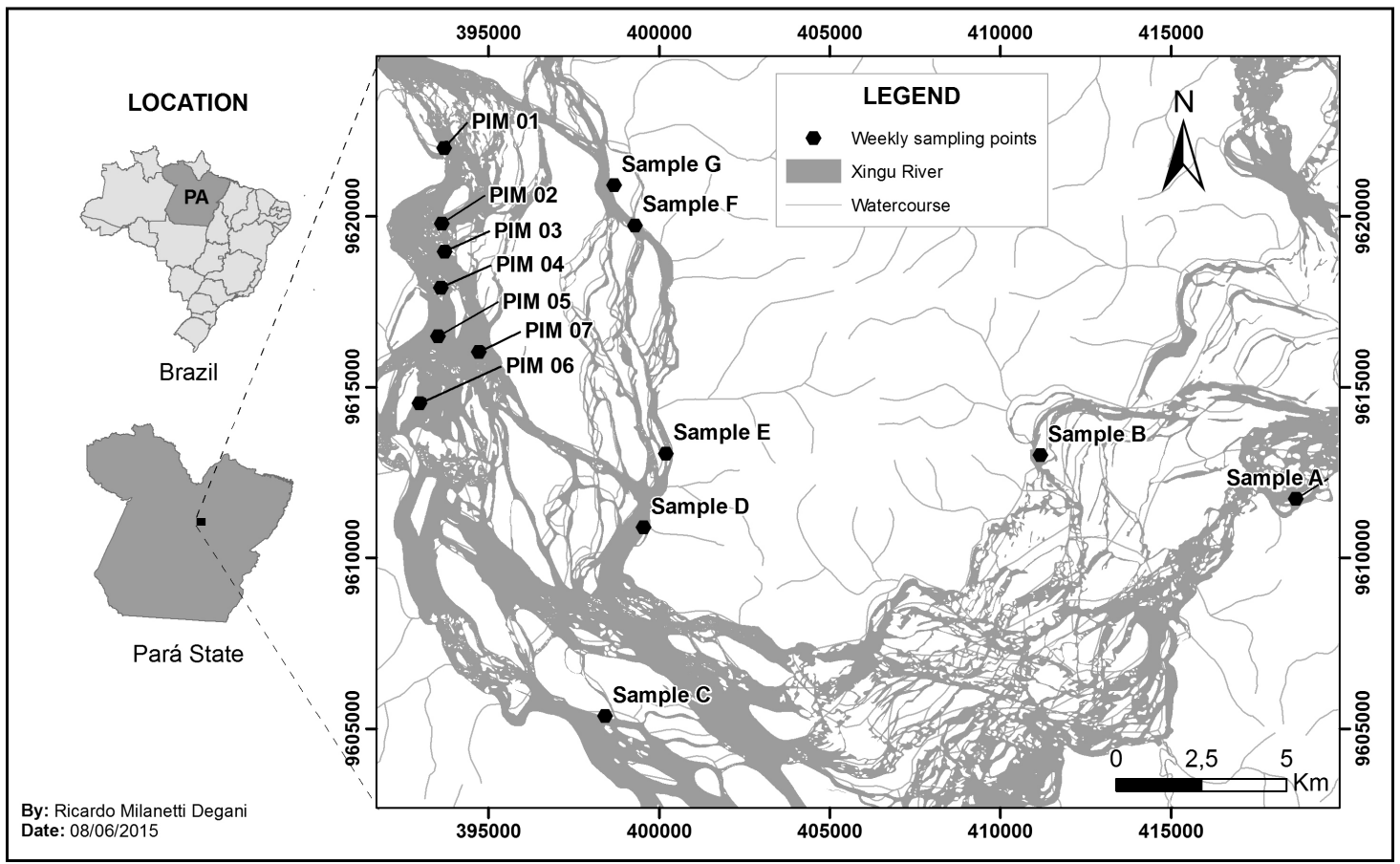

Figure 5. The geographical distribution of the weekly sampling stations.

\subsubsection{Sampling methods for sediment analysis}

Sediment analysis was performed in the laboratory after collecting samples with special equipment: Eckman Birge Sample or plastic spatulas. Sample were frozen before analysis; chemical analysis were carried out for total nitrogen, total phosphorus, particulate carbon (organic and inorganic) and metals: Aluminium, Cooper; Cadmium, Lead, Cromium, total Iron; dissolved iron; Zinc, Manganese, Magnesium, Arsenium, Mercury and Selenium. A granulometric analysis of the sediment was carried out simultaneously (Munawar, 2003). 


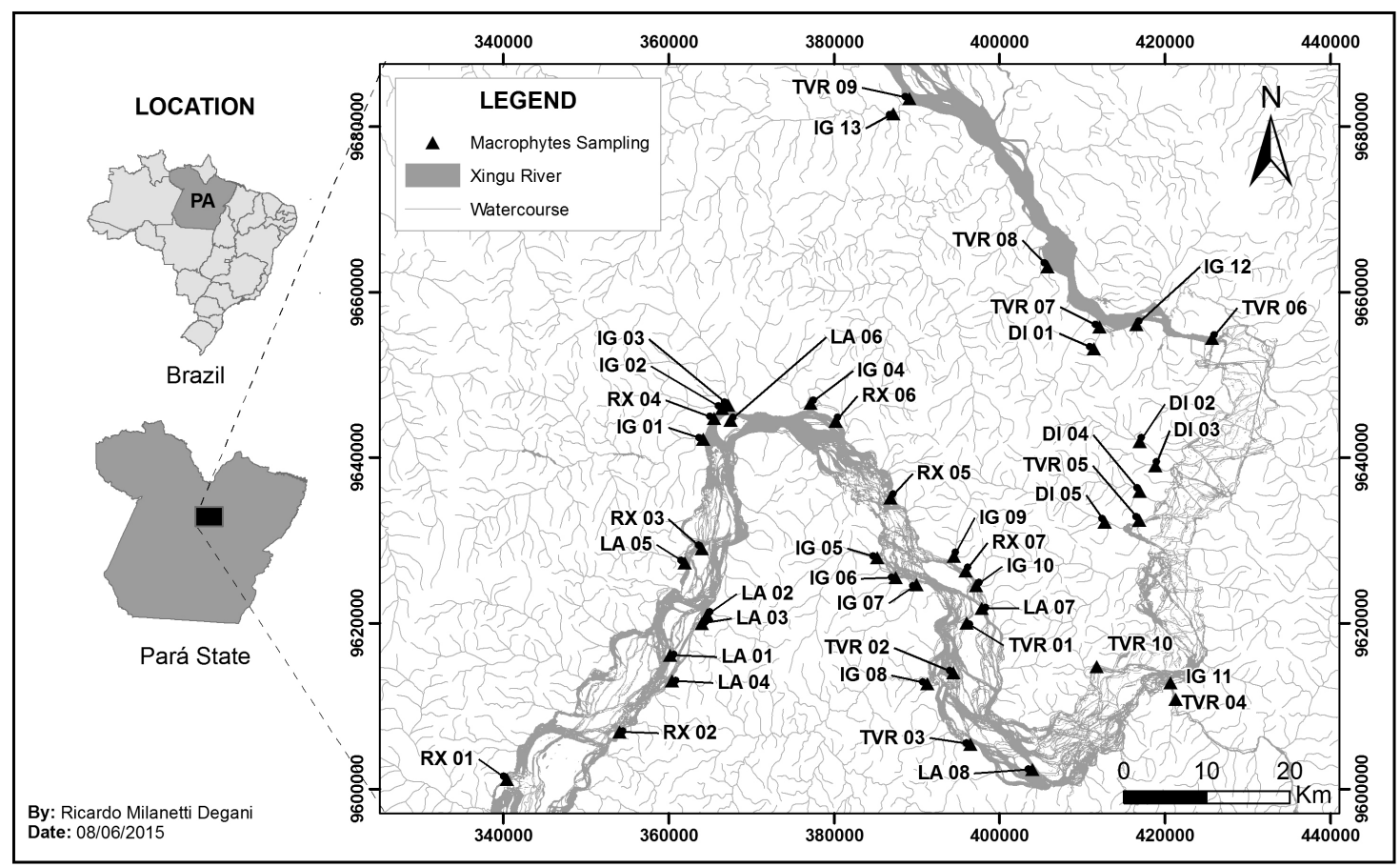

Figure 6. The geographical distribution of macrophyte sampling.

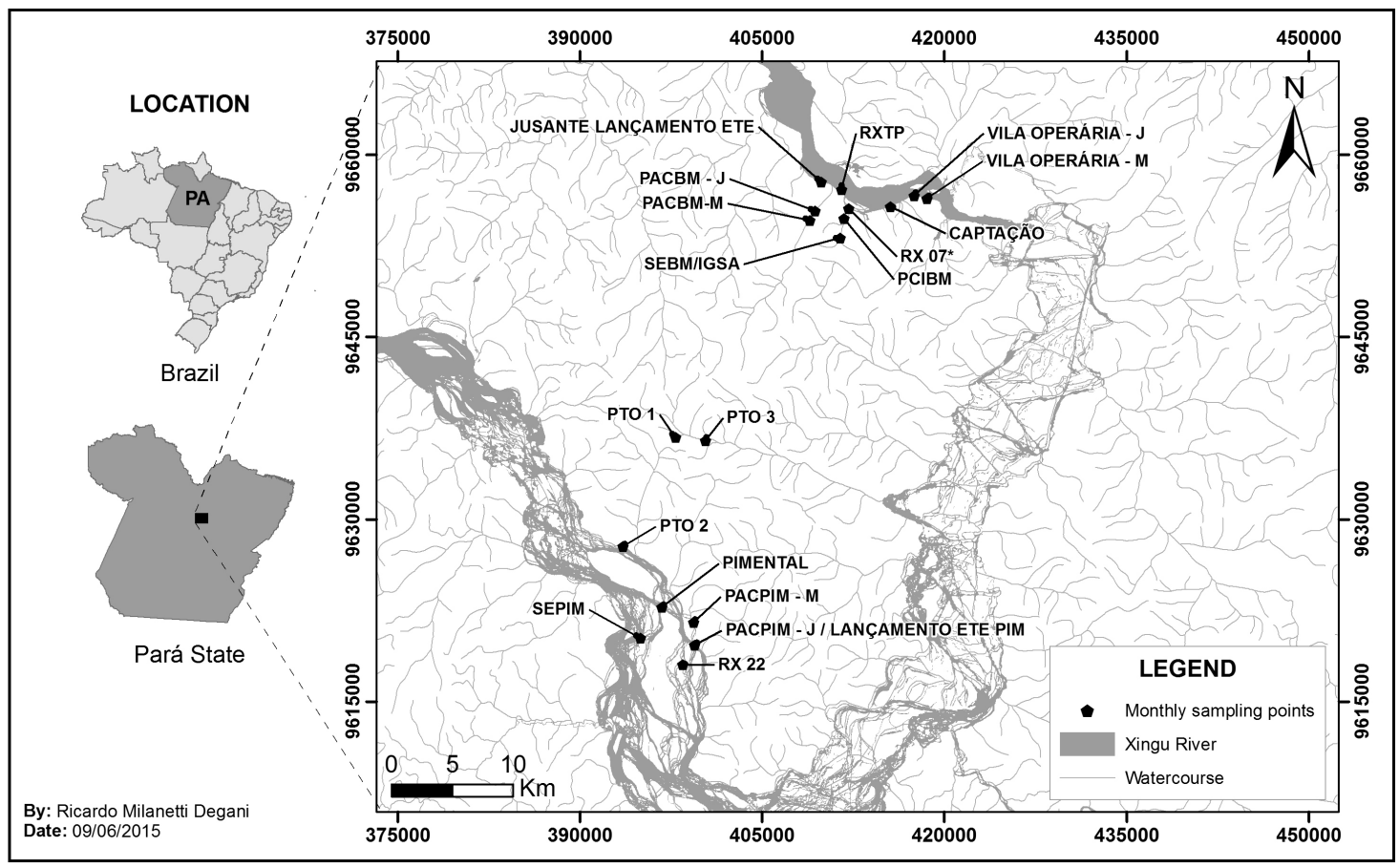

Figure 7. The geographical distribution of the monthly sampling points.

\subsubsection{Biological assessments}

Most organisms of the aquatic biota are sensitive to changes in the environment, due to natural causes (changes in flow, turbidity, consequences of heavy rainfall) or manmade impacts such as pollution and discharge of contaminants or remains of construction works, or other effects on the water quality or on the physical structure of rivers. Different organisms respond to in different ways: mass death; migration; changes in metabolism; changes in number of species; extinction. The study of organisms "in situ" can produce a series of informations on water quality about impacts. Sampling with standardized methods and 
Table 1. Physical, chemical and biological variables monitored and the analytical methods utilized on the sampling strategy at Xingu River.

\begin{tabular}{|c|c|c|c|}
\hline \multicolumn{4}{|c|}{ SURFACE WATER } \\
\hline VARIABLES & UNITY & METHOD & BASIC REFERENCES \\
\hline Depth & $\mathrm{m}$ & Depth Measurer & Speedtech Instruments \\
\hline $\mathrm{pH}$ & $\mathrm{pH}$ units & Multiparametric sensors & YSI Incorporated \\
\hline Electrical Conductivity & $\mu \mathrm{S} / \mathrm{cm}$ & Multiparametric sensors & YSI Incorporated \\
\hline Turbidity & UNT & Multiparametric sensors & YSI Incorporated \\
\hline Dissolved Oxygen & $\mathrm{mg} / \mathrm{L}$ & Multiparametric sensors & YSI Incorporated \\
\hline Saturation of D.O. & $\%$ & Multiparametric sensors & YSI Incorporated \\
\hline Water Temp. & ${ }^{\circ} \mathrm{C}$ & Multiparametric sensors & YSI Incorporated \\
\hline Total Suspended Solids & $\mathrm{mg} / \mathrm{L}$ & Multiparametric sensors & YSI Incorporated \\
\hline Redox Potential & $\mathrm{mV}$ & Multiparametric sensors & YSI Incorporated \\
\hline Transparency & $\mathrm{m}$ & Secchi Disk & Wetzel and Likens (1991) \\
\hline Apparent color & $\mathrm{mg} \mathrm{PtCo/L}$ & Spectrophotometry & APHA et al. (1998) \\
\hline True color & $\mathrm{mg} \mathrm{PtCo} / \mathrm{L}$ & Spectrophotometry & APHA et al. (1998) \\
\hline Suspended Organic Matter & $\mathrm{mg} / \mathrm{L}$ & Gravimetry & Wetzel and Likens (1991) \\
\hline Alkalinity & $\mathrm{mg}-\mathrm{CaCO}_{3} / \mathrm{L}$ & Titrimetry with $\mathrm{H}_{2} \mathrm{SO}_{4}$ & APHA et al. (1998) \\
\hline BOD $_{5,20}$ & $\mathrm{mg} / \mathrm{L}$ & $\begin{array}{c}\text { Incubation \& Titration } \\
\text { (Winkler) }\end{array}$ & APHA et al. (1998) \\
\hline Total Phosphorus & $\mu g-P / L$ & $\begin{array}{l}\text { Colorimetric Method } \\
\text { Spectrophotometry }\end{array}$ & Valderrama (1981) \\
\hline Total Nitrogen Kjeldhall & $\mathrm{mg}-\mathrm{NTK} / \mathrm{L}$ & Acid Digestion & APHA et al. (1998) \\
\hline Nitrite & $\mu g-N / L$ & Liquid Chromatography & APHA et al. (1998) \\
\hline Nitrite & $\mu g-N / L$ & Liquid Chromatography & APHA et al. (1998) \\
\hline Amonium & $\mu g-N / L$ & Liquid Chromatography & APHA et al. (1998) \\
\hline Fluoride & $\mu \mathrm{g} / \mathrm{L}$ & Liquid Chromatography & APHA et al. (1998) \\
\hline Cloride & $\mathrm{mg} / \mathrm{L}$ & Liquid Chromatography & APHA et al. (1998) \\
\hline Bromide & $\mu \mathrm{g} / \mathrm{L}$ & Liquid Chromatography & APHA et al. (1998) \\
\hline Lithium & $\mu \mathrm{g} / \mathrm{L}$ & Liquid Chromatography & APHA et al. (1998) \\
\hline $\begin{array}{l}\text { Phosphate (organic; } \\
\text { inorganic) }\end{array}$ & $\mu g-P / L$ & Liquid Chromatography & APHA et al. (1998) \\
\hline Sulphate & $\mathrm{mg} / \mathrm{L}$ & Liquid Chromatography & APHA et al. (1998) \\
\hline Sodium & $\mathrm{mg} / \mathrm{L}$ & Liquid Chromatography & APHA et al. (1998) \\
\hline Potassium & $\mathrm{mg} / \mathrm{L}$ & Liquid Chromatography & APHA et al. (1998) \\
\hline Magnesium & $\mathrm{mg} / \mathrm{L}$ & Liquid Chromatography & APHA et al. (1998) \\
\hline \multirow[t]{2}{*}{ Calcium } & $\mathrm{mg} / \mathrm{L}$ & Liquid Chromatography & APHA et al. (1998) \\
\hline & $\mathrm{mg} / \mathrm{L}$ & Extraction soxhlet & APHA et al. (1998) \\
\hline $\begin{array}{l}\text { Metals (Al, } \mathrm{Cu}, \mathrm{Fe}, \mathrm{Cd} \\
\mathrm{Pb}, \mathrm{Cr}, \mathrm{Mn}, \mathrm{Zn}, \mathrm{As}, \mathrm{Hg} \\
\mathrm{Ni}, \mathrm{Se})\end{array}$ & $\mathrm{mg} / \mathrm{L}$ & $\begin{array}{l}\text { Atomic Absorption } \\
\text { Spectrophotometer }\end{array}$ & APHA et al. (1998) \\
\hline Clorophyll a & $\mu \mathrm{g} / \mathrm{L}$ & $\begin{array}{c}\text { Extraction Etanol 80\% } \\
\text { Warm } \\
\text { Spectrophotometric } \\
\end{array}$ & Nusch (1980) \\
\hline Pesticides & $\mu \mathrm{g} / \mathrm{L}$ & $\begin{array}{c}\text { Methods USEPA } 8260 \\
8270 \\
8151,8082 \text { liquid } \\
\text { cromatography }\end{array}$ & APHA et al. (1998) \\
\hline Total coliforms & $\mathrm{NMP} / 100 \mathrm{~mL}$ & $\begin{array}{c}\text { Incubation in defined } \\
\text { substrate }\end{array}$ & APHA et al. (1998) \\
\hline \multicolumn{4}{|c|}{ SEDIMENT } \\
\hline Total phosphorus & $\mathrm{mg}-\mathrm{P} / \mathrm{g}$ sed & Colorimetric Method & Andersen (1976) \\
\hline Total Nitrogen Kjeldhal & mg-NTK/g sed & $\begin{array}{l}\text { Acid digestion, destilation, } \\
\text { titration }\end{array}$ & APHA et al. (1998) \\
\hline Organic Matter & $\%$ & Gravimetry & APHA et al. (1998) \\
\hline
\end{tabular}

Aquatic Macrophytes - gDW x m-2 (Moura Junior et al., 2015) 
Table 1. Continued...

\begin{tabular}{|c|c|c|c|}
\hline \multicolumn{4}{|c|}{ SURFACE WATER } \\
\hline VARIABLES & UNITY & METHOD & BASIC REFERENCES \\
\hline $\begin{array}{l}\text { Total carbon-inorganic } \\
\text { carbon }\end{array}$ & $\mathrm{mg} / \mathrm{g}$ sed & $\begin{array}{c}\text { Combustion at higt } \\
\text { temperature. Infrared } \\
\text { detection TOC }-5.000 \text {, } \\
\text { SSM }-5000 \mathrm{~A}\end{array}$ & APHA et al. (1998) \\
\hline $\begin{array}{l}\text { Metals (Al, } \mathrm{Cu}, \mathrm{Fe}, \mathrm{Pb}, \mathrm{Cr}, \\
\quad \mathrm{Mn}, \mathrm{Zn}, \mathrm{As}, \mathrm{Hg}, \mathrm{Ni})\end{array}$ & $\mathrm{mg} / \mathrm{Kg}$ sed & $\begin{array}{l}\text { USEPA 3050B ver. } 2 \text { - } \\
\text { atomic absorption }\end{array}$ & APHA et al. (1998) \\
\hline Granulmetry & $\%$ & & APHA et al. (1998) \\
\hline $\begin{array}{c}\text { Pesticides (11 types } \\
\text { - organochlorides, } \\
\text { organophosphorus, } \\
\text { carbamates. }\end{array}$ & $\mu \mathrm{g} / \mathrm{Kg}$ sed & $\begin{array}{l}\text { USEPA } 8270,8260 \mathrm{~B}, \\
8081,8082,8141 \text { - liquid } \\
\text { cromatography }\end{array}$ & APHA et al. (1998) \\
\hline \multicolumn{4}{|c|}{ AQUATIC BIOTA } \\
\hline $\begin{array}{c}\text { Phytoplankton \& } \\
\text { Cyanobacterias }\end{array}$ & org $/ \mathrm{ml}$ & \multicolumn{2}{|c|}{$\begin{array}{c}\text { Phytoplankton \& Cyanobacterias } \\
\text { Sant'Anna (1984) }\end{array}$} \\
\hline Zooplankton & $\operatorname{org} / \mathrm{m}^{3}$ & \multicolumn{2}{|c|}{ Pennak(1953), Matsumura-Tundisi (1999) } \\
\hline $\begin{array}{l}\text { Benthic macro } \\
\text { invertebrates }\end{array}$ & $\mathrm{Org} / \mathrm{m}^{2}$ & \multicolumn{2}{|c|}{ Mugnai et al. 2010} \\
\hline
\end{tabular}

Aquatic Macrophytes - gDW x m-2 (Moura Junior et al., 2015)

laboratory studies are an important and useful methodology to develop biological assessments (Chapman, 1992; Arocena and Conde, 1999).

Since the presence or absence of specific aquatic organisms depends on the physical environments, its associated habitats, and the water quality, sampling demonstrates the magnitude of the impacts.

\subsubsection{Methods for biological sampling}

\subsubsection{Phytoplankton}

60 liters of water were collected in the subsurface with a plastic bucket. The material was concentrated with a net mesh size $20 \mu \mathrm{m}$. Samples were dispensed in a plastic container of $250 \mathrm{ml}$ and fixed in formalin, $4 \%$. The analysis of the phytoplankton was carried out routinely with an optical microscope with 200x enlargement in a Sedgwick Rafter camera. Analysis of the phytoplankton with an inverted microscope, in sedimentation chambers was also performed. Sub samples of $1 \mathrm{ml}$ were examined routinely. Manuals and papers for phytoplankton identification, were those of Geitler (1932), Uthermöl (1958), Bicudo (1965), Prescott (1966), Huber-Pestalozzi (1968), Bourrely (1968, 1970, 1972), Bicudo and Bicudo (1970), Sant'Anna et al. (1988), Hustedt (1991), Komàrek (1991) and Bicudo et al.(2005). Density of organisms was expressed in organisms/litre. Classification of phytoplankton was made up to genera.

Sampling for cyanobacteria was performed with a collection of 250 milliliters of water, in the surface, preserved with formalin $2 \%$. Identification and determination of number of cells was carried out routinely by the use of a inverted microscope Zeiss; routinely samples were analyzed after sedimentation in chambers of 2,5, $10 \mathrm{ml}$. Density of organisms was expressed in number of cels $/ \mathrm{ml}$.

\subsubsection{Zooplankton}

Zooplankton samples were collected with a conic net in horizontal tows -mesh size of the net $68 \mu \mathrm{m}$.

Rotifers, Protozoa and Copepod nauplii were classified under binocular microscope with magnification of 200x; $1 \mathrm{ml}$ sub sample was dispensed in a Sedgwick Rafter camera.

Larges organisms such as Copepod and Cladocera were analyzed under a binocular microscope in 5-10 ml sub samples, with magnification of 100x.

Density of zooplankton organisms was expressed in number of organisms $/ \mathrm{m}^{3}$. References for zooplankton identification:Edmondson (1959), Koste (1978), Dussart (1984), Dussart and Defaye (2001), Matsumura-Tundisi et al. (1991), Matsumura-Tundisi and Silva (1999), Matsumura-Tundisi (1999), Smirnov (1971), Mizuno (1964) and El Moor-Loureiro (1997).

\subsubsection{Benthic macro invertebrates}

Sampling was carried out by using a quick net; an Eckman-Petersen collector for organic sediment; a Van Veen sampler for sandy or pebbles sediment. Samples were dispensed in plastic bottles and fixed with formalin $8 \%$. In the laboratory samples were sorted out, biological material was analyzed under binocular microscope with a magnification of $100 \%$. Classification up to family was used for macro invertebrates. Density of organisms was expressed in number $/ \mathrm{cm}^{3}$ sediment.

References for benthic organisms identification: Pérez (1996) and Mugnai et al. (2010).

\subsubsection{Aquatic macrophytes}

The occurrence of aquatic macrophytes was carried out by visualization of the species, both on the water and in the margins for the identification of amphibian forms. Unidentified plants by viewing were collected and placed 
between sheets of newspaper, cardboard, pressed between wooden slats, kept in an oven for at $40^{\circ} \mathrm{C}$ for $72 \mathrm{~h}$ and then kept in a freezer at $-20^{\circ} \mathrm{C}$ for $96 \mathrm{~h}$ for assembly of herbarium specimens.

To determine the biomass, 3 square plots of $0.5 \times 0.5 \mathrm{~m}$ were sampled, washed to remove debris and dried at $70^{\circ} \mathrm{C}$ until constant weight. The biomass was obtained by the dry weight (DW) per unit of area expressed in gDW. $\mathrm{m}^{-2}$.

A qualitative assessment of aquatic macrophytes infestation was performed at each sampling site, assigning the following scale: Level 0: absence of macrophytes; Level I: only the presence; Level II: mild infestation; Level III: medium infestation; Level IV: severe infestation; and Level V: critical infestation. Fauna associated with aquatic macrophytes was also studied and classified up to family (Moura Junior et al., 2015).

\section{Discussion}

The methodology of sampling and the design of limnological surveys and research followed the conditions of structure and function of the Xingu River ecosystem, and its spatial and temporal complexity. The evaluation of the water quality parameters were also permanently compared with the Brazilian environmental regulations for water quality (CONAMA 357) and the designed water use. Geographical features of the region, the water uses (present and future), pollution sources and the hydrological cycles, were the main features that were the basis for the assessment programme. The spatial distribution of water, quality with great number of stations, the evaluation of trends with high frequency of sampling on in depth inventories with pollutants, were the basis of the monitoring of water quality, established. The operations on water quality assessment and limnological surveys, also, followed the strategies of: basic surveys, operational surveillance, emergency surveys, impact surveys, and early warning surveillance as described by Chapman (1992), Carlson (1977) and Tundisi and Matsumura-Tundisi (2008, 2012, 2013b).

\section{Perspectives}

The multipurpose monitoring carried out at the Xingu River in the region of influence of the future Belo Monte Power Plant is a information system that will be fundamental to assess the water quality and the limnological status of the river, as well as to provide a basis for the development of future scenarios when the reservoirs starts their operation (Colwell et al., 2004). The data bank this provided with the intensive sampling is fundamental also to be the basis for the modeling effort prepared for evaluating impacts on the water quality and for designing mitigation strategies. River/ reservoir ecosystems, support a wide variety of activities such as water supply for drinking water, irrigation, navigation and recreation, besides, as in the case of Belo Monte Power Plant units, production of energy (Garzon, 1984; Junk and Mello, 1987). Progressive urbanization, pollution, and new economic developments triggered by the Power Plant units, will affect water quality, the river/reservoir limnology and the aquatic biota at all trophic levels. The organization and operation of a limnological survey and water quality assessment is a fundamental process and a platform that will lay the foundations for a follow up of the future changes that certainly will occur at the Belo Monte Power Plant Unit and Xingu River (Tundisi, 1999; Brasil, 2001; Jorgensen et al., 2012).

\section{References}

AGOSTINHO, AA., BONECKER, CC., RODRIGUES, H., GOMES, LC. and THOMAZ, SM., 2009. Biodiversity and Conservation. Brazilian Journal of Biology = Revista Brasileira de Biologia, vol. 69, no. 2, supplement, p. 459-755.

ALLAN, D., 1995. Stream ecology structure and funcioning of running waters. Oxford: Chapman \& Hall.

American Public Health Association - APHA, American Water Works Association - AWWA and World Economic Forum WEF, 1998. Standard methods for the examination of water and wastewater. 20th ed. Washington: APHA/AWWA/WEF.

AMSLER, LM., AMSLER, ML., BLETTLER, MCM. and EZCURRA DE DRAGO, I., 2009. Influence of hydraulic conditions over dunes on the distribution of benthic macroinvertebrates in a large sand bed river. Water Resources Research, vol. 45, no. 6, Article ID: W06426.

ANDERSEN, JM., 1976. An ignition method for the determination of total phosphorus in lake sediments. Water Research, vol. 10, no. 4, p. 329-331. http://dx.doi.org/10.1016/0043-1354(76)90175-5.

AROCENA, R. and CONDE, D., 1999. Métodos en ecología de águas continentales. Montevideo: Universidad de la República. $233 \mathrm{p}$.

BARROW, CJ., 1983. The environment consequences of water resource development it the tropics. In BEE, OJ. (Ed.). Natural resource in tropical countries. Singapore: Singapore University Press. p. 439-476.

BETTLER, CMM., AMSLER, ML., DRAGO, IE., BULLO, JM., PAINA, AR., DRAGO, E., ESPINOLA, LA., FONTANA, LO., EBERLE, E., RODRIGUES-CAPÍTULO, A., 2014. Long term morphologic and hydrologic effects on benthic invertebrates: in a minor channel of the Paraná River floodplain (Argentina). Ecological Engineering, vol. 67, p. 134-143.

BICUDO, CM. and BICUDO, RMT., 1970. Algas de águas continentais brasileiras. São Paulo: Fundação Brasileira para o Desenvolvimento do Ensino de Ciências. 228 p.

BICUDO, CM., 1965. Contribuição ao conhecimento das algas de água doce do Parque do Estado de São Paulo: quatro espécies de Dinobryon Ehrenb. Rickia, vol. 2, p. 81-87.

BICUDO, CM., BICUDO, MEC. and MENEZES, M., 2005. Gêneros de algas de águas continentais do Brasil. Chave para identificação e descrições. São Carlos: Rima Editora. 508 p.

BOURRELY, P., 1968. Lês algues d'eau Douce. Initiation à la systematique: les algues jaunes et brunes. Paris: Boubée e Cie. Tomo II. $468 \mathrm{p}$.

BOURRELY, P., 1970. Lês algues d'eau douce. Initiation à la systematique: eugléniens, péridinies, algues rouges et algues bleues. Paris: Boubée e Cie. Tomo III. 512 p. 
BOURRELY, P., 1972. Lês Algues d'eau douce. Initiation à la systematique: les algues vertes. Paris: Boubée e Cie. Tomo I. 572 p.

Brasil. Conselho Nacional do Meio Ambiente-CONAMA, 2005. Resolução COMANA n ${ }^{\circ}$ 357, de 17 DE março de 2005. Dispõe sobre a classificação dos corpos de água e diretrizes ambientais para o enquadramento, bem como estabelece as condições $e$ padrões de lançamento de efluentes, e dá providências. Diário Oficial da União, Brasília, 18 mar. p. 58-63.

Brasil. Conselho Nacional do Meio Ambiente-CONAMA, 2012. Resolução CONAMA $n^{\circ} 454$, de de 01 de novembro de 2012. Estabelece as diretrizes gerais e os procedimentos referenciais para o gerenciamento do material a ser dragado em águas sob jurisdição nacional. Diário Oficial da União, Brasília, 01 jan. Seção 1, p. 66.

Brasil. Ministério do Meio Ambiente - MMA. Secretaria de Biodiversidade e Florestas - SBF, 2001. Biodiversidade na Amazônia Brasileira: avaliação e ações prioritárias, uso sustentável e repartição de beneficios. Brasília: MMA/SBF.

CARLSON, RE., 1977. A trophic state index for lakes. Limnology and Oceanography, vol. 22, no. 2, p. 361-380. http://dx.doi. org/10.4319/lo.1977.22.2.0361.

CHAPMAN, D. (Ed.), 1992. Water quality assessments: a guide to the use of biota, sediments and water in environmental monitoring. Cambridge: UNEP/WHO/UNESCO. 585 p.

COLWELL, RK., MAO, CX. and CHANG, J., 2004. Interpolating, extrapolating, and comparing incidence-based species accumulation curves. Ecology, vol. 85, no. 10, p. 2717-2727. http://dx.doi. org/10.1890/03-0557.

DUSSART, BH. and DEFAYE, D., 2001. Introduction to the copepoda. Leiden: Backhuys Publishers. 344 p.

DUSSART, BH., 1984. Some crustacea copepoda from Venezuela. Hidrobiologia, vol. 113, no. 1, p. 25-67. http://dx.doi.org/10.1007/ BF00026592.

EDMONDSON, WT., 1959. Freshwater biology. 2nd ed. Seatle: University of Washington. $1248 \mathrm{p}$.

EL MOOR-LOUREIRO, LMA., 1997. Manual de identificação de Cladóceros Límnicos do Brasil. Brasília: Universa-UCB. 156 p.

GARZON, C., 1984. Water quality in hydrelectric projects: considerations for planning in tropical forest regions. Washington: The World Bank. World Bank Technical Paper Number, no. 20.

GEITLER, L., 1932. Cyanophyceae. In RABENHORST, L. (Ed.). Kryptogammenflora von Deutschland, Osterreich, under de Sweitz. Leipzig: Akademische Verlagsgesellschaft. vol. 14, p. 673-1056.

HUBER-PESTALOZZI, G., 1968. Das phytoplankton dês susswassers: systematik und biologie: Cryptophyceae, Chlormonadophyceae, Dinophyceae. Stuttgart: Schweizbartsch Verlagsbuchhandlung. $132 \mathrm{p}$.

HUSTEDT, F., 1991. Bacillariophyta. In PASCER, A. (Ed.). Die susswasser flora mittelleuropas. 2nd ed. Jena: G. Fischer. vol. 10, $466 \mathrm{p}$.

Instituto Brasileiro do Meio Ambiente e dos Recursos Naturais Renováveis - IBAMA, 2013. Avaliação de impacto ambiental. procedimentos e metodologia. Brasília: IBAMA. p. 1-18.

JORGENSEN, SE., TUNDISI, JG. and MATSUMURA TUNDISI, T., 2012. Handbook of inland aquatic ecosystem management. Rondon: Taylor \& Francis. $422 \mathrm{p}$
JUNK, WJ. and MELLO, N., 1987. Impactos ecológicos das represas hidroelétricas na Bacia Amazônica brasileira. Estudos Avançados, vol. 4, no. 8, p. 126-143.

KOMÀREK, I.,1991. A review of waterbloom forming Microcystis species, with regard to populations from Japan. Algological Studies, vol. 64, p. 115-127.

KOSTE, W., 1978. Rotatoria. Die rädertiere mitteleuropas. Berlin: Getrüder Borntraeger. 234 p.

MARGALEF, R., 1993. Limnologia. Barcelona: Ediciones Omega. 1003 p.

MARTINELLI, LA., PINTO, AS., NARDOTO, GB., OMETTO, JPHB., FILOSO, S., COLETTA, LD. and RAVAGNANI, EC., 2012. Nitrogen mass balance in the brazilian Amazon: an update. Brazilian Journal of Biology $=$ Revista Brasileira de Biologia, vol. 72, no. 3, supplement, p. 683-690.

MATSUMURA-TUNDISI, T. and SILVA, W. M., 1999. Crustáceos Copépodos Planctônicos. In ISMAEL, D., VALENTI, WC., MATSUMURA-TUNDISI, T. and ROCHA, O. (Orgs.). Biodiversidade do Estado de São Paulo, Brasil: sintese do conhecimento ao final do século XX: invertebrados de água doce. São Paulo: Fapesp. 97 p.

MATSUMURA-TUNDISI, T., 1999. Diversidade de zooplâncton em represas do Brasil. In HENRY, R. (Ed.). Ecologia de reservatórios: estrutura, função e aspectos sociais. Botucatu: FUNDIBIO/FAPESP. p. 39-54.

MATSUMURA-TUNDISI, T., TUNDISI, JG., SAGGIO, A., OLIVEIRA NETO, AL. and ESPÍNDOLA, EG., 1991. Limnology of Samuel Reservoir (Brazil, Rondonia) in the filling phase. Verhandlungen des Internationalen Verein Limnologie, vol. 24, p. $1428-1487$.

MIZUNO, T., 1964. Illustrations of the freshwater plankton of Japan. Osaka: Hoikusha Publishing. 356 p.

MOURA JÚNIOR, EG., PAIVA, RMS., FERREIRA, AC., PACOPAHYBA, LD., TAVARES, AS., FERREIRA, FA. and POTT, A., 2015. Updated chechlist of macrophytes from Northern Brazil. Acta Amazonica, vol. 45, no. 2, p. 111-132. http://dx.doi. org/10.1590/1809-4392201402662.

MUGNAI, R., NESSIMIAN, JL. and FERNANDES BAPTISTA, D., 2010. Manual de identificação de macroinvertebrados aquáticos do Estado do Rio de Janeiro. Rio de Janeiro: Technical Books Editora. $176 \mathrm{p}$.

MUNAWAR, M. (Ed.), 2003. Sediment quality assessment and managment: insight and progress. East Lansing: AEHM/ Michigan State University Press. 361 p. Ecovision World Monograph Series.

NUSCH, EA., 1980. Comparation of different methods for chlorophyll and phaeopigment determination. Archiv für Hydrobiologie-Beiheft Ergebnisse der Limnologie, vol. 14, p. 14-36.

PENNAK, RW., 1953. Fresh water invertebrates of the United States. New York: The Ronald Press Company. 769 p.

PÉREZ, GR., 1996. Guía para el Estudio de los macroinvertebrados acuáticos del departamento de antioquia. Antioquia: Fondo Fen/ Colciencias/Universidad de Antioquia. 217 p.

PRESCOTT, GW., 1966. Algae of the western great lake area. Dubuque: WMC. Brown Company Publishers. 577 p.

REVENGA, C., MUMAY, S., ABRAMOVITZ, J. and HAMMOND, A., 1998. Watersheds of the world: ecological value and vulnerability. Washington: WRI. $164 \mathrm{p}$. 
SANT’ANNA, CL., 1984. Chroococcales (Chlorophyceae) do Estado de São Paulo, Brasil. Bibliografia Phycollogica, vol. 67, p. 1-348.

SANT'ANNA, CL., XAVIER, MB. and SORMUS, L., 1988. Estudo do fitoplâncton da represa de Serraria, Estado de São Paulo, Brasil. Brazilian Journal of Biology $=$ Revista Brasileira de Biologia, vol. 48, no. 1, p. 83-102.

SIOLI, H., 1975. Tropical river: the Amazon. In WHITON, BA. (Ed.). River ecology. studies in ecology. Oxford: Blackwell Scientific Publications. vol. 2, p. 461-486.

SIOLI, H., 1984. The Amazon: limonology and landscape ecology of a mighty tropical river and its basin. Dordrecht: Dr. W. Junk Publishers. $763 \mathrm{p}$.

SMIRNOV, NN., 1971. Fauna of the U.S.S.R. Crustacea. St. Petersburg: Zoological Institute of Russian Academy of Sciences. $644 \mathrm{p}$.

STRASKRABA, M. \& TUNDISI, JG., 2000. Gerenciamento de qualidade da água de represas. São Carlos: International Lake Environmental Commite. 300 p. Diretrizes para o gerenciamento de lagos, no. 9.

TUNDISI, JG. and MATSUMURA-TUNDISI, T., 2008. Limnologia. São Paulo: Oficina de Textos. 632 p.

TUNDISI, JG. and MATSUMURA-TUNDISI, T., 2012. Limnology. Florence: Taylor \& Francis. 864 p.

TUNDISI, JG. and MATSUMURA-TUNDISI, T., 2013a. Biodiversity and development of the Amazon Watershed. Proceedings Brazilian Academy of Science. In press.
TUNDISI, JG. and MATSUMURA-TUNDISI, T., $2013 \mathrm{~b}$. Limnologia. São Paulo: Oficina de Textos. 632 p.

TUNDISI, JG. and STRASKRABA, M., 1999. Theoretical reservoir ecology and its applications. Ann Arbor: International Institute of Ecology. 585 p.

TUNDISI, JG., 1999. Limnologia no século XXI: perspectivas e desafios. In Caderno de Resumos do VII Congresso Brasileiro de Limnologia, 1999, Florianópolis. Florianópolis: UFSC. p. 24.

TUNDISI, JG., MATSUMURA-TUNDISI, T. and TUNDISI, JEM., 2008. Reservoir and human well being: new challenges for evaluating impacts and benefits in the neotropics. Brazilian Journal of Biology $=$ Revista Brasileira de Biologia, vol. 68, no. 4, supplement, p. 1133-1135.

UTHERMÖL, H., 1958. Zur Vervollkommung der quantitativen Phytoplankton metodik. Stuttgart: Schweizerbart. p. 1-38. Internationale Vereinigung f. Theoretische u. Angewandte Limnologie, no. 9.

VALDERRAMA, JC., 1981. The simultaneous analysis of total nitrogen and total phosphorus in natural water. Marine Chemistry, vol. 10, no. 2, p. 102-122. http://dx.doi.org/10.1016/03044203(81)90027-X.

WETZEL, RG. and LIKENS, GE., 1991. Limnological analyses. New York: Springer-Verlag.

WHITON, BA. (Ed.), 1975. River ecology. studies in ecology. Oxford: Blackwell Scientific Publications. vol. 2, 725 p. 
Annex A. List of sampling stations in the lower Xingu River.

Table 1A. Monthly sampling stations.

\begin{tabular}{|c|c|c|c|}
\hline \multirow{2}{*}{ REGION } & \multirow{2}{*}{ SITE } & \multicolumn{2}{|c|}{ LOCATION } \\
\hline & & $\mathbf{E}^{\mathbf{a}}$ & $\mathbf{S}^{\mathbf{b}}$ \\
\hline \multirow{13}{*}{$\begin{array}{l}\text { Belo Monte } \\
\text { Construction } \\
\text { Site }\end{array}$} & PCIBM & 411710 & 9654776 \\
\hline & PACBM-J & 409329 & 9655379 \\
\hline & RXTP & 411518 & 9657155 \\
\hline & SEBM/IGSA & 411411 & 9653158 \\
\hline & PACBM-M & 408904 & 9654630 \\
\hline & RX-07 & 412101 & 9655603 \\
\hline & Downstream & & \\
\hline & wastewater & & \\
\hline & treatment & & \\
\hline & plant & 409813 & 9657777 \\
\hline & Water intake & & \\
\hline & for drinking & & \\
\hline & purposes & 411636 & 9656065 \\
\hline \multirow{2}{*}{$\begin{array}{l}\text { Workers } \\
\text { Village }\end{array}$} & & 418528 & 9656427 \\
\hline & & 417479 & 9656648 \\
\hline \multirow{9}{*}{$\begin{array}{c}\text { Main } \\
\text { Reservoir } \\
\text { Construction } \\
\text { Site }\end{array}$} & PACPIM-J/ & & \\
\hline & Downstream & & \\
\hline & wastewater & & \\
\hline & treatment & & \\
\hline & plant & 399414 & 9617647 \\
\hline & PACPIM - M & 399313 & 9621524 \\
\hline & SEPIM & 394953 & 9620243 \\
\hline & RX 22 & 393341 & 9616080 \\
\hline & PIMENTAL & 396711 & 9622747 \\
\hline Channel & PTO 1 & 397829 & 9636748 \\
\hline Construction & PTO 2 & 393499 & 9627763 \\
\hline and Dikes & PTO 3 & 401950 & 9636672 \\
\hline
\end{tabular}

${ }^{\mathrm{a}} \mathrm{E}$ (East). ${ }^{\mathrm{b}} \mathrm{S}$ (South) coordinates expressed in Universal Transverse Mercator (UTM).

Table 2A. Weekly sampling sites near main reservoir.

\begin{tabular}{|c|c|c|c|}
\hline \multirow{2}{*}{ REGION } & \multirow{2}{*}{ SITE } & \multicolumn{2}{|c|}{ LOCATION } \\
\hline & & $\mathbf{E}^{\mathbf{a}}$ & $\mathbf{S}^{\mathbf{b}}$ \\
\hline \multirow{7}{*}{$\begin{array}{l}\text { XINGU } \\
\text { RIVER }\end{array}$} & PIM 1 & 393707 & 9622013 \\
\hline & PIM2 & 393625 & 9619797 \\
\hline & PIM 3 & 393721 & 9618982 \\
\hline & PIM 4 & 393606 & 9617918 \\
\hline & PIM 5 & 393517 & 9616490 \\
\hline & PIM 6 & 392994 & 9614535 \\
\hline & PIM 7 & 394720 & 9616038 \\
\hline
\end{tabular}

${ }^{\mathrm{a}} \mathrm{E}$ (East). ${ }^{\mathrm{b}} \mathrm{S}$ (South) coordinates expressed in Universal Transverse Mercator (UTM). 
Table 3A. Weekly monitoring transmission lines.

\begin{tabular}{|c|c|c|c|}
\hline \multirow{2}{*}{ REGION } & \multirow{2}{*}{ SITE } & \multicolumn{2}{|c|}{ LOCATION } \\
\hline & & $\mathbf{E}^{\mathbf{a}}$ & $\mathbf{S}^{\mathbf{b}}$ \\
\hline \multirow{4}{*}{ ROADS } & PACBM-M & 408918 & 9654830 \\
\hline & IGATU & 416616 & 9654462 \\
\hline & IGCHOCAÍ & 420015 & 9654208 \\
\hline & PCIBM & 411710 & 9654776 \\
\hline $\begin{array}{c}\text { DASH KM } \\
50\end{array}$ & $\mathrm{SEBM}=\mathrm{IGSA}$ & 411411 & 9653158 \\
\hline $\begin{array}{c}\text { DASH KM } \\
40\end{array}$ & IGTR40 & 401380 & 9659722 \\
\hline \multirow{2}{*}{ EAST-WEST } & PTO 02 & 393499 & 9627763 \\
\hline & IGLH & 394393 & 9627799 \\
\hline \multirow{4}{*}{$\begin{array}{c}\text { DASH KM } \\
55\end{array}$} & IGPAQ & 412785 & 9632254 \\
\hline & IGTIC & 416972 & 9635945 \\
\hline & IGCAJ & 416759 & 9639494 \\
\hline & IGCO & 416941 & 9641996 \\
\hline \multirow{5}{*}{$\begin{array}{c}\text { DASH KM } \\
27\end{array}$} & IGPAQ-M1 & 396299 & 9638667 \\
\hline & IGPAQ-M2 & 396333 & 9638686 \\
\hline & PACPIM-J & 401942 & 9621770 \\
\hline & IGARAPÉ TRV & \multirow{2}{*}{401773} & \multirow{2}{*}{9624030} \\
\hline & 27 & & \\
\hline
\end{tabular}

${ }^{\mathrm{a}} \mathrm{E}$ (East). ${ }^{\mathrm{b}} \mathrm{S}$ (South) coordinates expressed in Universal Transverse Mercator (UTM).

Table 4A. Sampling sites every three months.

\begin{tabular}{|c|c|c|c|}
\hline \multirow{2}{*}{ REGION } & \multirow{2}{*}{ SITE } & \multicolumn{2}{|c|}{ LOCATION } \\
\hline & & $\mathbf{E}^{\mathbf{a}}$ & $\mathbf{S}^{\mathbf{b}}$ \\
\hline $\begin{array}{c}\text { UPSTREAM FUTURE } \\
\text { XINGU RIVER RESERVOIR }\end{array}$ & RX 19 & 340308 & 9594378 \\
\hline \multirow{12}{*}{$\begin{array}{c}\text { XINGU } \\
\text { RIVER IN } \\
\text { THE SITE OF } \\
\text { FUTURE } \\
\text { XINGU RIVER } \\
\text { RESERVOIR }\end{array}$} & RX01 & 364567 & 9622460 \\
\hline & RX 02 & 364825 & 9642028 \\
\hline & PAN 02 & 362587 & 9642191 \\
\hline & ALT 02 & 364918 & 9646170 \\
\hline & AMB 02 & 367145 & 9646750 \\
\hline & RX 18 & 369016 & 9645307 \\
\hline & RX 24 & 380375 & 9643752 \\
\hline & RX 25 & 385884 & 9627996 \\
\hline & RX 03 & 393609 & 9621881 \\
\hline & IGLH & 394393 & 9627799 \\
\hline & IDM & 397174 & 9624564 \\
\hline & PIMENTAL* & 395955 & 9619993 \\
\hline \multirow{11}{*}{$\begin{array}{c}\text { DOWNSTREAM } \\
\text { XINGU RIVER } \\
\text { RESERVOIR } \\
\text { (VOLTA GRANDE) }\end{array}$} & $\mathrm{RX} 23$ & 399847 & 9611758 \\
\hline & RESSACA* & 395716 & 9605109 \\
\hline & FAZENDA* & 397063 & 9605831 \\
\hline & RX04 & 398892 & 9604506 \\
\hline & RX20 & 410981 & 9612559 \\
\hline & RX05 & 419119 & 9611979 \\
\hline & RX06 & 422128 & 9613197 \\
\hline & BAC02 & 423341 & 9608322 \\
\hline & $\mathrm{BAC} 03$ & 436647 & 9595949 \\
\hline & $\mathrm{RX} 21$ & 416882 & 9632483 \\
\hline & RX17 & 423568 & 9654245 \\
\hline
\end{tabular}

${ }^{\mathrm{a}} \mathrm{E}$ (East). ${ }^{\mathrm{b}} \mathrm{S}$ (South) coordinates expressed in Universal Transverse Mercator (UTM). *Pimental, Ressaca and Fazenda are local names of sites. 
Table 4A. Continued...

\begin{tabular}{cccc}
\hline \multirow{2}{*}{ REGION } & \multirow{2}{*}{ SITE } & $\mathbf{E}^{\mathbf{a}}$ & $\mathbf{S}^{\mathbf{b}}$ \\
\cline { 2 - 3 } & & LOCATION & 9654208 \\
\cline { 2 - 3 } & IGCHOCAÍ & 420015 & 9655929 \\
\hline SITES OF & RX11 & 420042 & 9632254 \\
FUTURE & IGPAQ & 412785 & 9635945 \\
MIDDLE & IGTIC & 416972 & 9639036 \\
RESERVOIR & IGCAJ & 418862 & 9641996 \\
\cline { 2 - 3 } & IGCO & 416941 & 9648416 \\
DOWNSTREAM & TURIÁ & 414127 & 9657260 \\
POWER PLANT & RX 07 & 412421 & 9653158 \\
IN THE XINGU & SEBM/IGSA & 411411 & 9682481 \\
RIVER & TUC 01 & 388040 & 9688205 \\
\cline { 2 - 3 }
\end{tabular}

${ }^{\mathrm{a}} \mathrm{E}$ (East). ${ }^{\mathrm{b}} \mathrm{S}$ (South) coordinates expressed in Universal Transverse Mercator (UTM). *Pimental, Ressaca and Fazenda are local names of sites. 